\title{
DISASTER PREPAREDNESS IN SAGAY CITY
}

\begin{tabular}{c}
${ }^{*}$ Robert S. Pardillo \\
I**abelita Perigua \\
\hline Paper Received: 24.02.2020 / Paper Accepted: 30.05.2020 / Paper Published: 02.06.2020 \\
\hline Corresponding Author: Robert S. Pardillo; Email: dabert1216@yahoo.com; doi:10.46360/globus.xxxxxxxx \\
\hline
\end{tabular}



\section{Introduction}

Natural and human-induced disasters are rampant in certain areas around the globe especially in disaster-prone and risk - vulnerable countries. In the Philippines, where most of the provinces are susceptible to natural and human-induced disaster, disaster risk management acquires gradually more crucial to the government's interference (Nakagawa, 2013).

Super typhoon "Yolanda" is the most powerful and devastating tropical cyclone that struck the Philippines in recent memory. The Category 5 typhoon made its first landfall over Guiuan, Eastern Samar in the early morning of November 8, 2013, and wreaked havoc, primarily on the Visayas region, until its exit from the Philippine area of responsibility the following day (GMA News Online, 2013).

With the monstrous effect of Super Typhoon Yolanda, the government disaster preparedness has been exposed. The weaknesses and significant gaps in the country's disaster response and management system were revealed once more. Despite a solid and functioning disaster risk reduction and management (DRRM) structure, the government's responses still came across as reactive and not proactive, insufficient, inefficient and for the most part, too slow (Osal 2016).

According to Sagay City Research and Planning Office, most of the island barangay in Sagay were greatly affected by calamities. In the hazard Assessment Profile report in 2014 released by Sagay City - Office of the City Mayor it was revealed that $100 \%$ of the barangays in Sagay were under threat by typhoons, earthquake, fire and epidemic outbreak. Furthermore, in the flood assessment conducted by the city, $12 \%$ or 3 barangay were affected by flooding. Also, three barangays were prone to coastal erosion and storm surge. These are Brgy, Himoga - An Baybay, Brgy, Old Sagay, and Brgy, Molocaboc where schools are also situated.

Sagay City had been devastated by Typhoon Yolanda, most especially the island barangays of Sagay. The researcher had seen the areas personally as he visited the islands of Molocaboc, Suyac, and Matabas in the relief operation and stress debriefing activity together with his officers. Such

*Professor, CHMSC, Talisay City, Philippines. Email: dabert1216@yahoo.com.

** Professor, USLS, Bacolod City, Philippines. 
encounter revealed that people in the island take refuge to houses that are concrete during the strike of ST Yolanda. They did not consider the school as a safe place to stay. Schools in the Division of Sagay do not even have the assessment tools in measuring the preparedness of the school, personnel, and students regarding the disaster.

As Youth Formation Program Division Coordinator, the researcher has a strong motivation to conduct this research for the protection of school children when disaster comes. Furthermore, as Red Cross Program Coordinator and Gawad KALASAG (Kalamidad at Sakuna Labanan, Sariling Galing ang Kaligtasan) Focal person of the Division of Sagay, the researcher has decided to conduct this study to formulate plans and policies for disaster preparedness in Sagay City schools.

The study was anchored on Republic Act 10121 otherwise known as "Philippine Disaster Risk Reduction and Management Act of 2010. It provides a systematic outline to guide implementers a very clear path on disaster preparedness. The Social Cognitive Theory supports it. Social Cognitive Theory in the context of disaster preparedness showed that people's motivation to prepare for disasters is a function of the cognitive and affective reactions to a natural hazard. When individuals are motivated, intentions to prepare are formed by their outcome expectancies and self-efficacy.

\section{Statement of the Problem}

This study aimed to assess the extent of disaster preparedness in the public elementary and secondary schools in the Division of Sagay City, Negros Occidental during the school year 2015 2016. Specifically, it sought to answer the following questions:

1. What is the profile of all public schools in the Division of Sagay City in terms of:
i. School Location,
ii. Number of School Classrooms,
iii. Type of School Building, and
iv. Source of DRRM fund?

2. What is the profile of all public school administrators in the Division of Sagay City in terms of:
a. Age and
b. Sex?
c. What is the profile of all public school teachers in the Division of Sagay City in terms of:
i. Age,
ii. Sex, and
iii. Teachers' Qualification?

d. What is the profile of students in the Division of Sagay City in terms of:
i. Grade Level and
ii. Age?

e. What is the level of disaster preparedness of implementing schools in the Division of Sagay City in the following areas and when they are grouped according to variables?
i. School Buildings and Facilities,
ii. Program and Project Implemented,
iii. Schools as Evacuation Centers, and
iv. Teachers' and Students' Training?

f. Is there a significant difference in the disaster preparedness of implementing schools in the Division of Sagay City in different areas and when grouped according to school profile, school administrators, teachers, and students?

g. Is there a significant relationship on the disaster preparedness of implementing schools in the Division of Sagay City on different areas and when grouped according to school profile, school administrators, teachers, and students?

\section{Methodology \\ Research Instrument and Sources of Data}

This study utilized the descriptive survey method in data collection. It was supplemented by the focus group discussion to validate the primary data gathered from the survey and acquire a deeper understanding of the issue involved. The study was conducted in the Division of Sagay City in all public elementary and secondary schools for the academic year 2016 - 2017. Respondents of this study are the 61 school administrators, 267 teachers and 379 students of the 65 elementary and secondary schools of the Division of Sagay City. They were selected through sampling.

This study is limited only to asses the extent of disaster preparedness of all schools in the Division of Sagay city particularly on the four thematic areas: Preparedness of School Buildings and Facilities, Programs and Project Implemented by the school, Preparedness of school as Evacuation Center, and Preparedness of Teachers and Students. The researcher anchored the questionnaire from the Gawad KALASAG checklist developed by the Office of the Civil defense. The questionnaire is composed of two main parts namely: Part I is the respondent's profile, and Part II is the survey 
profile, and it was subjected to the reliability and validity test.

Procedure for Data Analysis

To provide answers to the problems of the study, frequency, mean and percentage were used as descriptive statistics. For determining the level of significance and correlation, t-test and Analysis of variance, and Pearson Product Moment Correlation were used. All data were computer- processed.

\section{Result and Discussion}

Profile of all Public Schools

Table 1: Profile of Public Schools in the Division of Sagay City

\begin{tabular}{|c|c|c|}
\hline Variables & $f$ & $\%$ \\
\hline \multicolumn{3}{|l|}{ School Location } \\
\hline Central & 10 & 16.4 \\
\hline Upland & 34 & 55.7 \\
\hline Coastal & 17 & 27.9 \\
\hline $\begin{array}{l}\text { Total } \\
\text { Number of School Classroom }\end{array}$ & 61 & 100 \\
\hline 10 classrooms and below & 39 & 63.9 \\
\hline 11 - 15 classrooms & 12 & 19.7 \\
\hline $16-20$ classroom & 4 & 6.5 \\
\hline 21 classrooms and above & 6 & 9.8 \\
\hline Total & 61 & 100 \\
\hline \multicolumn{3}{|l|}{ Type of School Building } \\
\hline SEDP & 5 & 8.2 \\
\hline Marcos Type & 7 & 11.5 \\
\hline Gabaldon Type & 9 & 14.8 \\
\hline PCCI & 6 & 9.8 \\
\hline DPWH & 24 & 39.3 \\
\hline Others & 10 & 16.4 \\
\hline $\begin{array}{l}\text { Total } \\
\text { Source of DRRM Fund }\end{array}$ & 61 & 100.0 \\
\hline MOOE & 51 & 83.6 \\
\hline Canteen & 2 & 3.3 \\
\hline PTA & 7 & 11.5 \\
\hline Others & 1 & 1.6 \\
\hline Total & 61 & 100.0 \\
\hline
\end{tabular}

Generally, most of the schools are located in the upland areas and mostly have ten classrooms and below. 39.3\% of the classrooms are DPWH designed. Regarding Disaster preparedness, Maintaining Operating and Other Expenses (MOOE) school fund is the main source of fund.

Profile of all Public Schools Administrators

Table 2: Profile of the Public Schools Administrators in the Division of Sagay City

\begin{tabular}{lcc}
\hline Variables & $f$ & \% \\
\hline Age & & \\
$\quad$ Younger & 29 & 47.5 \\
$\quad$ Older & 32 & 52.5 \\
Total & 61 & 100.0 \\
Sex & & \\
Male & 24 & 43.1 \\
Female & 37 & 56.9 \\
$\quad$ Total & 61 & 100.0 \\
\hline
\end{tabular}

The profiles of the Public School Administrators in the Division of Sagay City mostly are older with 52.50\%, and the majority of them with $56.90 \%$ are females. 
Profile of all Public Schools Teachers

Table 3: Profile of the Public Schools' Teachers in the Division of Sagay

\begin{tabular}{lcc}
\hline Variables & $\boldsymbol{f}$ & $\mathbf{\%}$ \\
\hline Age & & \\
Younger & 141 & 52.8 \\
Older & 126 & 47.2 \\
Total & 267 & 100.0 \\
Sex & & \\
$\quad$ Male & 41 & 15.4 \\
$\quad$ Female & 226 & 84.6 \\
Total & 267 & 100.0 \\
Teachers Qualification & & \\
With MA units & 187 & 70.0 \\
$\quad$ Master's Degree & 51 & 19.1 \\
$\quad$ With Doctoral Units & 27 & 10.1 \\
$\quad$ Pd. D. Ed D. & 2 & 0.7 \\
Total & $\mathbf{2 6 7}$ & $\mathbf{1 0 0 . 0}$ \\
\hline
\end{tabular}

Mostly the teachers in the Division of Sagay City are younger, with $52.8 \%$, the majority are females with $84.6 \%$, and $70 \%$ of the teachers have units in the Master's Degree.

Profile of The Students

Table 4: Profile of the Students Respondents in the Division of Sagay City

\begin{tabular}{lcc}
\hline Variables & $f$ & $\mathbf{~}$ \\
\hline Grade Level & 213 & 56.2 \\
Intermediate & 132 & 34.8 \\
Junior High School & 34 & 9.0 \\
Senior High School & 379 & 100.0 \\
$\quad$ Total & & \\
Age & 212 & 56.0 \\
$\quad 12$ years old and below & 88 & 23.2 \\
13 to 15 years old & 79 & 20.8 \\
$\quad$ 16 years old and above & 379 & 100.0 \\
Total & & \\
\hline
\end{tabular}

Most of the students - respondents are in their intermediate years with $56.2 \%$, and the majority of them ages 12 years old and below with $56 \%$.

Level of Disaster Preparedness of the Implementing Schools

Table 5: Level of Disaster Preparedness of the Implementing Schools as Assessed by School Administrators, Teachers, and Students

\begin{tabular}{|l|c|c|c|c|c|c|c|c|c|}
\hline \multirow{2}{*}{$\begin{array}{l}\text { Areas of School } \\
\text { Preparedness }\end{array}$} & \multicolumn{3}{|c|}{ Administrators } & \multicolumn{3}{c|}{ Teachers } & \multicolumn{3}{c|}{ Students } \\
\cline { 2 - 11 } & $\mathbf{M}$ & SD & $\begin{array}{c}\text { Interpre } \\
\text {-tation }\end{array}$ & $\mathbf{M}$ & SD & $\begin{array}{c}\text { Interpre } \\
\text {-tation }\end{array}$ & M & SD & $\begin{array}{c}\text { Interpre } \\
\text {-tation }\end{array}$ \\
\hline $\begin{array}{l}\text { Preparedness of School } \\
\text { buildings and Facilities }\end{array}$ & 3.38 & 0.73 & Moderate & 3.61 & 0.78 & High & 3.99 & 0.61 & High \\
\hline $\begin{array}{l}\text { Preparedness on Programs } \\
\text { and Projects Implemented } \\
\text { by the School }\end{array}$ & 3.88 & 0.57 & High & 3.94 & 0.74 & High & 4.12 & 0.60 & High \\
\hline $\begin{array}{l}\text { Preparedness of School as } \\
\text { Evacuation Center }\end{array}$ & 3.32 & 0.89 & Moderate & 3.69 & 0.83 & High & 3.98 & 0.68 & High \\
\hline $\begin{array}{l}\text { Preparedness of Teachers } \\
\text { and Students Trainings }\end{array}$ & 3.30 & 0.94 & Moderate & 3.54 & 0.99 & High & 4.05 & 0.77 & High \\
\hline As a Whole & 3.44 & 0.73 & High & 3.68 & 0.79 & High & 4.03 & 0.60 & High \\
\hline
\end{tabular}


On the level of disaster preparedness of the implementing schools as assessed by administrators, teachers and students revealed that when taken as a whole in the four areas are high except on the area of preparedness of school buildings and facilities as perceived by administrators as moderate. It is because those administrators are the ones that plan, formulate programs and projects for the school related to disaster preparedness. Thus, the administrators know very well if programs formulated by her office was duly implemented or not. Furthermore, administrators are also the approving authority for every proposal presented by the teachers and students, and it might be that for the administrator's point of view disaster preparedness for teachers and students are not enough.

Table 6: Significant Differences on the Level of Disaster Preparedness of the Implementing Schools as Assessed by School Administrators when Grouped According to Age

\begin{tabular}{|c|c|c|c|c|c|c|c|}
\hline Areas of Preparedness Practices & Age & Mean & Sd & Df & t & $\mathbf{P}$ & $\begin{array}{l}\text { Interpre- } \\
\text { tation }\end{array}$ \\
\hline $\begin{array}{l}\text { Preparedness of School buildings and } \\
\text { Facilities }\end{array}$ & $\begin{array}{l}\text { Younger } \\
\text { Older }\end{array}$ & $\begin{array}{l}3.18 \\
3.56\end{array}$ & $\begin{array}{l}0.73 \\
0.69\end{array}$ & 49 & -1.91 & 0.06 & $\begin{array}{c}\text { Not } \\
\text { Significant }\end{array}$ \\
\hline $\begin{array}{l}\text { Preparedness on Programs and } \\
\text { Projects Implemented by the School }\end{array}$ & $\begin{array}{l}\text { Younger } \\
\text { Older }\end{array}$ & $\begin{array}{l}3.72 \\
4.03\end{array}$ & $\begin{array}{l}0.58 \\
0.52\end{array}$ & 49 & -2.03 & 0.05 & Significant \\
\hline $\begin{array}{l}\text { Preparedness of School a Evacuation } \\
\text { Center }\end{array}$ & $\begin{array}{l}\text { Younger } \\
\text { Older }\end{array}$ & $\begin{array}{l}3.10 \\
3.52\end{array}$ & $\begin{array}{l}1.02 \\
0.71\end{array}$ & 49 & -1.74 & 0.09 & $\begin{array}{c}\text { Not } \\
\text { Significant }\end{array}$ \\
\hline $\begin{array}{l}\text { Preparedness of Teachers and } \\
\text { Students Trainings }\end{array}$ & $\begin{array}{l}\text { Younger } \\
\text { Older }\end{array}$ & $\begin{array}{l}3.06 \\
3.51 \\
\end{array}$ & $\begin{array}{l}1.07 \\
0.75\end{array}$ & 49 & -1.76 & 0.09 & $\begin{array}{c}\text { Not } \\
\text { Significant }\end{array}$ \\
\hline As a Whole & $\begin{array}{l}\text { Younger } \\
\text { Older }\end{array}$ & $\begin{array}{l}3.20 \\
3.66 \\
\end{array}$ & $\begin{array}{l}0.90 \\
0.47\end{array}$ & 49 & -2.33 & 0.02 & Significant \\
\hline
\end{tabular}

Furthermore, the result presented in this table can be interpreted to mean that younger and older school administrators differ significantly in their perceptions of the level of disaster preparedness of the implementing school. Older administrators implement more programs on disaster preparedness compared to their younger counterpart. The reason for having a significant difference in the area of programs and projects implemented is that the long experience they have as older administrators. As senior administrators, they wanted to make sure that the school implements more programs and projects on disaster preparedness. They wanted to make sure that the school where they are assigned as school head are ready when disaster strikes. Level of Disaster Preparedness of the Implemeting Schools when grouped according to school location.

Table 7: Level of Disaster Preparedness of the Implementing Schools when Grouped According to School Location

\begin{tabular}{|c|c|c|c|c|c|c|c|c|c|}
\hline \multirow{2}{*}{$\begin{array}{l}\text { Preparedness } \\
\text { Practices }\end{array}$} & \multicolumn{3}{|c|}{ Central } & \multicolumn{3}{|c|}{ Upland } & \multicolumn{3}{|c|}{ Coastal } \\
\hline & M & SD & $\begin{array}{l}\text { Interpre- } \\
\text { tation }\end{array}$ & M & SD & $\begin{array}{l}\text { Interpre- } \\
\text { tation }\end{array}$ & M & SD & $\begin{array}{c}\text { Interpre- } \\
\text { tation }\end{array}$ \\
\hline $\begin{array}{l}\text { Preparedness of } \\
\text { School buildings and } \\
\text { Facilities }\end{array}$ & 3.48 & 0.56 & High & 3.32 & 0.58 & Average & 3.42 & 0.99 & High \\
\hline $\begin{array}{l}\text { Preparedness on } \\
\text { Programs and } \\
\text { Projects Implemented } \\
\text { by the School }\end{array}$ & 4.2 & 0.53 & High & 3.72 & 0.57 & High & 3.98 & 0.51 & High \\
\hline $\begin{array}{l}\text { Preparedness of } \\
\text { School as Evacuation } \\
\text { Center }\end{array}$ & 3.74 & 0.6 & High & 3.05 & 0.98 & Average & 3.54 & 0.72 & High \\
\hline $\begin{array}{l}\text { Preparedness of } \\
\text { Teachers and } \\
\text { Students Trainings }\end{array}$ & 3.69 & 0.87 & High & 2.96 & 0.99 & Average & 3.62 & 0.73 & High \\
\hline As a Whole & 3.78 & 0.58 & High & 3.2 & 0.85 & Average & 3.64 & 0.47 & High \\
\hline
\end{tabular}

Additionally, in the area of Teachers' and Students' Training, respondents of schools from central and coastal have high level while teachers assigned in the upland has a mean score of 2.96 which is interpreted as average. This only means that most of the time coastal schools are prone from flooding and storm surge so therefore school personnel should be ready while upland schools are protected by mountains from strong winds. Furthermore, schools that have 21 and above number of classrooms have high level of preparedness. In terms of 
type of school building, the SEDF, PCCI, DPWH, PTA and another type of school building have high level of disaster preparedness. Level of Disaster Preparedness of Implementing schools as assessed by school administrators when grouped according to sex.

Table 8: Level of Disaster Preparedness of the Implementing Schools as Assessed by School Administrators when Grouped According to Sex

\begin{tabular}{|l|c|c|c|c|c|c|}
\hline Areas of Preparedness & \multicolumn{3}{|c|}{ Male } & \multicolumn{3}{|c|}{ Female } \\
\cline { 2 - 7 } & M & SD & Interpretation & M & SD & Interpretation \\
\hline $\begin{array}{l}\text { Preparedness of School } \\
\text { buildings and Facilities }\end{array}$ & 3.28 & 0.78 & Average & 3.46 & 0.70 & High \\
\hline $\begin{array}{l}\text { Preparedness on Programs } \\
\text { and Projects Implemented } \\
\text { by the School }\end{array}$ & 3.74 & 0.57 & High & 3.99 & 0.54 & High \\
\hline $\begin{array}{l}\text { Preparedness of School a } \\
\text { Evacuation Center }\end{array}$ & 3.23 & 0.72 & Average & 3.39 & 1.00 & Average \\
\hline $\begin{array}{l}\text { Preparedness of Teachers } \\
\text { and Students Trainings }\end{array}$ & 3.30 & 0.93 & Average & 3.29 & $0 . .96$ & Average \\
\hline As a Whole & 3.39 & 0.59 & Average & 3.48 & 0.84 & High \\
\hline
\end{tabular}

Further, the female school administrators assessed School Building and Facilities, Program and Project Implemented as high level while for female and male school administrators but when taken as whole male administrators scored average in the four areas. This is because male administrators are more focused on the physical aspect of the school just like ground improvement.

Among teachers, both young and old also both male and female, assessed the four areas as a high level of disaster preparedness practices. Therefore, among teachers they feel that there school and themselves are more prepared based on the results.

On the area of teachers and students training when, all four areas were assessed with high level except for the teachers with Master's Degree. Moreover, teachers with Ph.D./Ed.D. Degree assessed School Building and Facilities and Schools as Evacuation Centers with average level.

Among students, regarding grade level, all four areas were assessed as high, except for the junior high school students who assessed Program and Project Implemented by the school with a very high level of disaster preparedness.

Further, students as grouped according to age, assessed the level of disaster preparedness of the implementing school with high level except for students with 13 to 15 years old who assessed Program and Project Implemented by the school with very high level. Significant relationship on disaster preparedness

On the significant difference on the disaster preparedness of implementing schools in the
Division of Sagay City, the school profile is not significant among four areas except for school location on the teachers and students training and also the type of school building on school as an evacuation center.

For the school administrators, when grouped according to age, the areas of Program and Project Implemented by the school is significant while on other areas are not significant. While for grouping of school administrators according to sex, in the four areas, is not significant.

Among teachers, age and qualification are not significant in the assessment of the four areas of the level of preparedness.

Among students, the grade level is significant; it is because that high school student experienced the same level of preparedness when they were in the elementary. While when students are grouped according to the age, the result is not significant in the assessment of the four areas of the level of preparedness.

\section{Conclusion}

High levels of disaster preparedness were found to be dominant based on the school profile, as assessed by the school administrators, teachers, and students. High level signifies that the schools implementing the disaster preparedness program are performing on what is being asked and required by the Department of Education. However, the high level signifies a little above the average level which means that the schools need to improve more. 
A significant divergence can be noted among junior high school students, ages 13-15 years old assessed Program and Project Implemented by the school with a very high level of disaster preparedness. It signifies that schools have implemented well the programs and training among students belonging to the junior high school group. It signifies that this group of students was recipients of continuous program implementation. The need for more training and implementation among another group of students needs to be strengthened. In the four areas, the area Program and Project Implemented by the school were found to be significant among grade level of students but not significant in other variables and areas. It signifies that disaster preparedness is only dominant among program and project implementation but not on other three areas. The need to balance the implementation of disaster preparedness in the School Buildings and Facilities, Schools as Evacuation Centers and Teachers' and Students' Training needs to be given more attention and fully addressed.

\section{Recommendation}

Based on the results of the study, the following are recommended.

1. To the division office, the department needs to realign plans and program implementation, be given with enough appropriated budget, that would level of all four areas and that the level of preparedness should fully reach the highest level. Evaluation of school buildings be given attention, and in the establishment of school building the disaster preparedness should be included in the approval and acceptance of a plan and finished structure.

2. To the school administrators, there is a need to evaluate the implementation of the program among their respective schools. The need to balance out the implementation in all four areas is highly recommended. For any conduct of the program, teachers should be involved and should be required to participate in all four areas so to raise their awareness and increase participation. Also, these are a need to increase the budget allocation for their school funds during the School Improvement Planning for upgrading educational facilities for safer and hazard free school. Furthermore, conduct constant communication with the disaster risk reduction team in their locality and make updates to the school community. School leaders should include sustainable yearly activities in the disaster preparedness through educating the whole school community with the inclusion of parents, teachers, and students such as drills, first aid, and quick response. Also, the discussion of the DRRM program should be integrated into the school curriculum.
3. The Division Project Development Officer (DRRM) in coordination with the local government should work together and plan out a widespread and sustainable implementation of disaster preparedness. The schools and division offices should also give budget allocation for DRRM priority.

4. Teachers should undergo training and workshop on disaster risk reduction management that would help to increase to the highest level of preparedness. Teachers may integrate into the lesson the disaster preparedness.

5. All students should also undergo training and workshop on disaster preparedness.

Students' organization should integrate disaster preparedness activities in their yearly school activities.

6. Parents should be active participants and supporters to the school program and project on disaster preparedness concerning simple mitigation and prevention strategies.

\section{Conflict of Interest}

There is no Conflict of Interest in this work.

\section{References}

1. Agbay, A., (2011). The extent of Implementation of the Disaster Preparedness Program of Negros Occidental High School for Academic Year 2010-2011. Unpublished Master's Thesis.

2. Agarwal, Nidhi and Mishra, Sugam, (2010). "Impact of Foreign Direct Investment in Indian Economy". IIMT Souvenir National Conference on Challenges for Organizations in Dynamic Business Environment, 8-9.

3. Agarwal, Nidhi and Sharma, Madhu, (2007). "A Matter of Styles in Education". Asian Journal of Psychology \& Education, 69(5), 26; doi: 10.5281/zenodo.3813617.

4. Agarwal, Nidhi and Kumar, Puneet, (2009). "Reflection on the new Innovations for maximizing the learning in Teacher of Mathematics". International Journal Educational Herald, 38(2); 41, ISSN: 09740732. Available at SSRN: https://ssrn.com/abstract=3600864, http://doi.org/10.5281/zenodo.3826567.

5. Brett, A., (2012). College and University Disaster Management: The Impact of Leader Behavior on Response and Recovery from Disaster Commission on Audit. Disaster Management Practices in the Philippines: An Assessment National Disaster Risk Reduction and Management Plan 2011 - 2028.

6. Bodoso, Enna S. and Monge, Engr. Albert Joseph Gonzalo M., (2019). Personality Dimension and Its Relationship to On-The-Job Performance. Globus An International Journal 
of Management \& IT, 10(2); 1-7, ISSN: 0975$721 X$.

7. Daly, H.E. and Farley, J., (2001). Ecological Economics: Principles and Applications. Island Press, Washington, DC Department Memorandum No. 100, s. (2007). Training of Trainers on Disaster Risk Reduction and Orientation on the Utilization of DRRM Manual.

8. Das, P., (2010). Role and Capacity Building of School Teachers in Disaster Preparedness and Prevention.

9. DepEd Memo No.12 s 2011. Establishment of The Red Cross Youth Councils and Training Of Teachers In The Different Red Cross Services.

10. DepEd Order No. 55, s. 2007. Prioritizing the Mainstreaming of Disaster Risk Reduction Management in the School System and Implementation of Programs and projects Relative.

11. DepEd Educational Facilities Manual. Revised Edition of the 2007 Handbook on Educational Facilities - Integrating Disaster Risk Reduction in School Construction.

12. Descalsota, M., (2015). Disaster Management Program in Selected Schools in the Division of Sagay City.

13. Disaster Preparedness, (2013). The University of Texas at Austine. University of Texas Disaster Preparedness Training Programme. Introduction to Disaster Preparedness. http//www.ifrc .org.

14. Emergency Response and Crisis Management Technical Assistance Center, (2007). 2(5); Retrieved from https://rems.ed.gov/docs/ HH_Vol2Issue5.pdf

15. FEMA, (2005-2008). Getting Started, Building Support for Mitigation Planning. FEMA, Understanding Your Risks, Identifying Hazards and Estimating Losses.

16. FEMA, Developing the Mitigation Plan, Identifying Mitigation Actions and Implementation Strategies

17. Fothergill, A. and Peek, L.A., (2004). Poverty and disasters in the United States: A review of recent sociological findings. Natural Hazards, 32; 89-110.

18. Gallard, J.C., (2008). Disaster Prevention and Management Hyogo Framework for Action 2005-2015: ISDR International Strategy for Disaster Reduction International Strategy for Disaster Reduction www.unisdr.org/wcdr.

19. ISDR system joint work programme 20082009. Retrieved from https://www.unisdr.org /we/inform/publications/2572.

20. ISDR, (2002). Living with a Risk. A Global Review of Disaster Reduction Initiatives. Geneva ISDR (2006 - 2007). World Disaster
Reduction Campaign: Disaster Risk Reduction Begins at School.

21. ISDR, (2007). Words into Action: A Guide For Implementing the Hyogo Framework for Action, United Nations, www.unisdr.org.

22. Izadkhah, Y.O. and Hosseini, M., (2005). "Towards Resilient Communities in Developing Countries through Education of Children for Disaster Preparedness". International Journal of Emergency Management.

23. Mamogale, H., (2011). Assessing Disaster Preparedness of Learners and Educators in Soshanguve North Schools.

24. Nakagawa, K. and Shaw, R., (2004). "Social Capital: A Missing Link to Disaster Recovery." International Journal of Mass Emergencies and Disasters.

25. Nakagawa, K., (2013). A Study on Factors Related to Earthquake Preparedness by Family of Non-institutionalized Individuals with Severe Motor and Intellectual Disabilities.

26. Nicholson, W.C., (2005). "NFPA 1600: The New Standard for Emergency Management." Journal of Emergency Management.

27. Ozmen, F., (2006). "The level of preparedness of the schools for disasters from the aspect of the school principals".

28. Paton, D. and Johnston, D., (2001). Disaster Resilience. An Integrated Approach. Springfield, Illinois: Charles C. Thomas.

29. Paton, D., Smith, L., and Johnston, D.M., (2001). Volcanic hazards: Risk perception and preparedness. New Zealand Journal of Psychology, 29(2); 86-91.

30. Perry, R.W. and Lindell M.K., (2006). Emergency Planning. John Wiley and Sons, Inc.: U.S.A.

31. Republic Act 10121, (2010). "Philippine Disaster Risk Reduction and Management Act of 2010” Retrieved at http:// www.ndrrmc.gov.ph.

32. Responsibilities for a School Disaster Plan, (2007). Retrieved at www.newschools.org/files/ Facilities-8.doc

33. Sagwan, Surinder, (2019). Innovation in Instructional Strategies \& Design. Globus Journal of Progressive Education, 9(2); 43-45, ISSN: 2231-1335.

34. Shaw, R., (2004). "From disaster to sustainable community planning and development: the Kobe Experiences."

35. Shiwaku, K., (2007), "Essentials of school disaster education: example from Kobe, Japan", Disaster Management: Global Challenges and Local Solutions, Universities Press, Hyderabad.

36. Sutton, J. and Tierney, K., (2009). Disaster Preparedness: Concepts, Guidance, and Research. 
37. UNICEF Annual Report, (2014). Philippines. Retrieved from: http://www.unicef.org/about/ annualreport/files/Philippines_Annual_Report 2014.pdf.

38. UNDP, (2007). A Global Review: UNDP Support to Institutional and Legislative Systems for Disaster Risk Management. Retrieved from: www.undp.org/bcpr/documents/dru/ proj_fact/ILS_DRM_ Global_Review_Final_AP.doc.

39. UNISDR, (2004). Terminology: Basic terms of disaster risk reduction.
40. http://www.unisdr.org/files/7817_7819isdr terminology 11 UN/ISDR, Latin America and Caribbean, (2007). Measuring Progress in Disaster Risk Reduction, Americas Regional Overview 2005-2006.

41. Vickery, D.J., (2005). School Buildings and Natural Disasters. Retrieved from: http://unesdoc.org/images/0005/000502/05028 0eb World Risk Report 2012. Retrieved from: http://www.droughtmanagement.info/literature /UNU world_risk_report_2012_2012.pdf.

How to cite this article:

Pardillo, Robert S. and Perigua, Isabelita, (2020). Disaster Preparedness in Sagay City. Globus Journal of Progressive Education, 10(1): 92-100. 